\title{
Antimicrobial Resistance Profile and Biofilm Production of Microorganisms Isolated from Oropharynx of Rupornis magnirostris (Gmelin, 1788) and Caracara plancus (Miller, 1777)
}

\author{
Fernanda Alda da Silva, ${ }^{1,2}$ Sandrelli Meridiana de Fátima Ramos dos Santos Medeiros, ${ }^{3}$ \\ Sérgio Dias da Costa-Junior $\mathbb{D}^{3}{ }^{3}$ Ana Emília Medeiros Roberto, ${ }^{4}$ Sarah Brandão Palácio, ${ }^{3}$ \\ Reginaldo Gonçalves de Lima-Neto, ${ }^{4,5}$ Rejane Pereira Neves, ${ }^{4}$ Carolina Peixoto Magalhães, ${ }^{2}$ \\ José Eduardo Garcia, ${ }^{6}$ and Isabella Macário Ferro Cavalcanti ${ }_{(\mathbb{D})}^{1,3}$ \\ ${ }^{1}$ Universidade Federal de Pernambuco (UFPE), Laboratório de Microbiologia e Imunologia, \\ R. Alto do Reservatório-Alto José Leal, SN, Vitória de Santo Antão, PE 55608-250, Brazil \\ ${ }^{2}$ Universidade Federal de Pernambuco (UFPE), Laboratório de Anatomia, R. Alto do Reservatório-Alto José Leal, s/n, \\ Vitória de Santo Antão, PE 55608-250, Brazil \\ ${ }^{3}$ Universidade Federal de Pernambuco (UFPE), Setor de Microbiologia, Laboratório de Imunopatologia Keizo Asami (LIKA), \\ Av. Moraes Rego, 1235, Cidade Universitária, Recife, PE 50670-901, Brazil \\ ${ }^{4}$ Universidade Federal de Pernambuco (UFPE), Laboratório de Micologia Médica do Departamento de Micologia, \\ Av. Prof. Moraes Rego, s/n, Cidade Universitária, Recife, PE 50760-420, Brazil \\ ${ }^{5}$ Universidade Federal de Pernambuco (UFPE), Laboratório de Culturas e Pesquisas in vitro, \\ Departamento de Medicina Tropical, Av. da Engenharia, s/n, Cidade Universitária, Recife, PE 50670-420, Brazil \\ ${ }^{6}$ Universidade Federal de Pernambuco (UFPE), Laboratório de Biotecnologia e Fármacos, R. Alto do Reservatório-Alto José Leal, \\ SN, Vitória de Santo Antão, PE 55608-250, Brazil
}

Correspondence should be addressed to Sérgio Dias da Costa-Junior; sergio_dias16@hotmail.com and Isabella Macário Ferro Cavalcanti; isabella.cavalcanti@ufpe.br

Received 10 April 2020; Revised 11 June 2020; Accepted 15 June 2020; Published 10 July 2020

Academic Editor: Francesca Mancianti

Copyright (C) 2020 Fernanda Alda da Silva et al. This is an open access article distributed under the Creative Commons Attribution License, which permits unrestricted use, distribution, and reproduction in any medium, provided the original work is properly cited.

The aim of this preliminary study was to identify microorganisms with antimicrobial resistance profile and biofilm producers in oropharynx of Rupornis magnirostris and Caracara plancus. Six R. magnirostris and six C. plancus maintained in Triage Center for Wild Animals (CETAS) facilities were studied. Coagulase-positive staphylococci (CoPS), enterobacteria, and yeasts were identified by the biochemical analysis or MALDI-TOF mass spectrometry. The resistance profile of the microorganisms was analyzed according to CLSI. The biofilm production was evaluated by Congo red and violet crystal staining methods. Among the 12 birds, 10 presented strains of CoPS and/or enterobacteria with resistance profile, such as methicillin-resistant CoPS (MRCoPS), vancomycin-resistant CoPS (VR-CoPS), extended-spectrum $\beta$-lactamase-producing Enterobacteriaceae (ESBL), and Klebsiella pneumoniae carbapenemase- (KPC-) producing bacteria. Regards the fungal analysis, Candida spp., Cryptococcus spp., Rhodotorula mucilaginosa, R. glutinis, and Trichosporon coremiiforme were identified. All the Trichosporon coremiiforme strains were resistant to amphotericin $\mathrm{B}$, as well as all the Rhodotorula mucilaginosa exhibited resistance to fluconazole. Related to the biofilm production, among the 8 CoPS, 27 enterobacteria, and 10 yeasts isolates, 3, 16, and 7 strains were biofilm producers, respectively. Thus, the presence of these microorganisms in birds of prey is worrisome, highlighting its possible influence in the spread of infections in urban centers. 


\section{Introduction}

The hawk-carijó (Rupornis magnirostris) and the carcará (Caracara plancus) belong to the orders Falconiformes and Accipitriformes, respectively. Both species are widely distributed throughout the Americas, mainly in South America, and are well distributed in the Brazilian territory [1]. These animals inhabit different sorts of environments including urban areas, as well as hang around roadsides, forest edges, and pastures in search of food. These birds of prey have an important ecological role in the control of the numbers of the small animals, being considered top predators of food chains and webs, helping to maintain stable the ecological balance of the ecosystem, in which they live [2].

Birds of prey are considered bioindicators of environmental quality, due to their ecological role, but they are also affected by changes in the environmental conditions and can be indicators of the preservation of the habitat, to which they are inserted [2, 3]. In addition, some species, such as Rupornis magnirostris and Caracara plancus, can adapt to anthropogenic environments, thus being exposed to a wide assortment of chemical and biological compounds present in this environment [4]. Free-living birds of prey, as well as other groups of birds, can be considered reservoirs or even vectors of pathogens of importance for the poultry farms, since serological studies show that they are exposed to micro-organisms by contact with residues and farm runoff, by ingestion of contaminated carcasses, or by the contamination of heavy metals dispensed in the environment $[3,5]$.

This contact with anthropic areas, feeding on remnants of possibly contaminated human waste, also increases the contact of these birds of prey with antimicrobial resistant microorganisms [6-9]. In 2012, Radhouani et al. [6] identified multiresistant E. coli and enterococci isolates from faecal samples of the common buzzards (Buteo buteo), a medium to large bird of prey. Sousa et al. [7] suggested that birds of prey, such as Buteo buteo, Strix aluco, and Corvus corone, seem to be a reservoir of multidrug-resistant $S$. aureus and coagulase-negative staphylococci. Our research group has identified Enterobacteriaceae with resistance profile in rectal swabs present in gavião-carijó (Rupornis magnirostris), among them, E. coli, K. pneumoniae, and Salmonella spp. are resistant to ciprofloxacin and lots of beta-lactams [8]. These animals, besides being affected by infections caused by these microorganisms, can become reservoirs and potential disseminators of these agents owing to their migratory capacity [6-9].

Besides the possible colonization of these birds by resistant micro-organisms, these infectious agents may also be producers of virulence factors, such as biofilm. A biofilm consists of a group of sessile cells, mono- or multispecies, and may be of bacterial or fungal origin, which are adhered to a biotic or abiotic surface and surrounded by an organic polymer matrix, the exopolysaccharide (EPS). The physical structure of the biofilm contributes to antimicrobial resistance in some species of microorganisms and may explain the chronicity or recurrence of infections since microorganisms in a biofilm tend to be more resistant to antimicrobial agents and therefore require higher concentrations of these agents to inhibit or eradicate them [10].

Since the identification of microorganisms resistant to antimicrobials and biofilm producers in birds of prey is scarce, this preliminary study aims to identify these pathogens isolated from the oropharynx of Rupornis magnirostris and Caracara plancus. In this way, we intend to fill this gap in the scientific field and contribute to public health, since these species are present in anthropic environments and can become disseminators of these pathogens.

\section{Materials and Methods}

2.1. Animal Obtention. Six Rupornis magnirostris and six Caracara plancus were used, with different weights and ages, obtained from the Wild Animals Triage Center of the Environment agency of the Pernambuco (CETAS)-IBAMA (Brazilian Institute of the Environment and Renewable Natural Resources). The animals donated by the center are not able to be reinserted in nature due to mutilations in the wings or legs that prevent their free locomotion. These animals were assigned by the CETAS to the collection of the samples one day after they had been rescued from the nature, and they had not undergone antibiotic therapy. The research project has the license granted by the Ethics Committee on the Use of Animals (CEUA), the Center for Biosciences (CB) of UFPE, receiving the appropriate authorization in the process number 23076.045832/2016-42 and authorization of SISBIO with number 57230-1.

2.2. Samples Collection. The oropharynx samples were collected using sterile swabs, which were transferred to brain heart infusion broth (BHIB) (HiMedia ${ }^{\circledR}$, Mumbai, India) for the identification of coagulase-positive staphylococci (CoPS), tetrathionate broth (HiMedia ${ }^{\circledR}$, Mumbai, India) for the identification of Enterobacteriaceae, and Sabouraud broth (HiMedia ${ }^{\circledR}$, Mumbai, India) for the identification of yeasts. All samples were transported in a polystyrene box, suitably sealed to the Laboratory of Microbiology and Immunology of the Centro Acadêmico of Vitória, at the Federal University of Pernambuco (CAV/UFPE), and incubated at $35 \pm 2^{\circ} \mathrm{C}$ for $24 \mathrm{~h}$ for later identification of the microorganisms.

\subsection{Identification of Coagulase-Positive Staphylococci (CoPS).} Samples from the BHIB were seeded on Baird Parker agar (HiMedia ${ }^{\circledR}$, Mumbai, India) at $35 \pm 2{ }^{\circ} \mathrm{C}$ for $48 \mathrm{~h}$ for identification of CoPS. After incubation, the typical colonies of CoPS were submitted to Gram staining and biochemical tests such as catalase, coagulase, DNase, and mannitol production to confirm the presence of CoPS [11].

2.4. Identification of Enterobacteriaceae. Samples from tetrathionate broth were plated on MacConkey (Kasvi ${ }^{\circledR}$, Paraná, Brazil) agar and Salmonella Shigella agar (SS) (Kasvi ${ }^{\circledR}$, Paraná, Brazil) and reincubated at $35 \pm 2{ }^{\circ} \mathrm{C}$ for $24 \mathrm{~h}$. After incubation, the samples that presented microbial growth compatible with Enterobacteriaceae were submitted 
to biochemical tests, such as oxidase, lysine, urea, citrate, triple sugar iron (TSI), motility-indole-ornithine (MIO), phenylalanine, DNase, sucrose, and arabinose [12].

2.5. Identification of Yeasts. Homogenous inocula of yeast cells were grown and maintained on yeast extract peptone dextrose agar medium (YEPD) (HiMedia ${ }^{\circledR}$, Mumbai, India). Incubations were standardized at $24 \mathrm{~h}$, and strains were grown aerobically at $35 \pm 2^{\circ} \mathrm{C}$. In order to avoid changes in the protein expression pattern, the culture conditions and growth time were standardized as described above. All cultures were checked for purity prior to mass spectrometry (MALDI-TOF Autoflex III Bruker Laser Nd: YAG smartbeam, Bruker Daltonics Inc., USA/Germany) [13].

One single colony was directly deposited onto a 196 position target plate (Bruker Daltonics $\mathrm{GmbH}$ ), and two such deposits were made for each isolate. Aliquots of $1 \mu \mathrm{L}$ of $70 \%$ formic acid were added and mixed gently with the yeasts. When the liquid medium was almost evaporated, the preparation was overlaid with $1 \mu \mathrm{L}$ of saturated matrix solution $(75 \mathrm{mg} / \mathrm{mL}$ of $\alpha$-cyano-4-hydroxycinnamic acid (CHCA) in ethanol/water/acetonitrile $(1: 1: 1)$ with $0.03 \%$ trifluoroacetic acid (TFA) $\left(\right.$ Merck $^{\circledR}$, New York, USA). A total of 20 isolates $(2 \times 20$ spots $)$ were deposited per plate, and the matrix-sample was crystallized by air-drying at room temperature for 5 minutes [13].

The equipment used was MALDI TOF Autoflex III mass spectrometer (Bruker Daltonics Inc., USA/Germany) equipped with a $\mathrm{Nd}$ : YAG (neodymium-doped yttrium aluminium garnet; $\mathrm{Nd}$ : $\mathrm{Y}_{3} \mathrm{Al}_{5} \mathrm{O}_{12}$ ) laser of $1064 \mathrm{~nm}$, set to a $66 \%$ power. The mass range from 2,000 to $20,000 \mathrm{Da}$ was recorded using a linear mode with a delay of $104 \mathrm{~ns}$ and an acceleration voltage of $+20 \mathrm{kV}$. The resulting peak lists were exported to the software MALDI Biotyper ${ }^{\mathrm{TM}} 3.0$ (Bruker Daltonics, Bremen, Germany) where the final identifications were achieved.

\subsection{Identification of Resistance Profile}

2.6.1. Antimicrobial Susceptibility Tests for CoPS. The identification of resistance profiles of the micro-organisms was performed according to the Clinical and Laboratory Standards Institute [14]. Samples positive for CoPS were submitted to the disc diffusion method, as well as the microdilution test and agar screening, for the identification of methicillin-resistant CoPS (MR-CoPS) and vancomycinresistant CoPS (VR-CoPS).

For the disc diffusion method, the inoculums of the microorganisms were adjusted to 0.5 of the McFarland scale and seeded onto plates containing Müeller-Hinton agar. The cefoxitin (CTX) $(30 \mu \mathrm{g})$, teicoplanin (TEC) $(30 \mu \mathrm{g})$, oxacillin (OXA) (1 $\mu \mathrm{g})$, and vancomycin (VAN) (5 $\mu \mathrm{g})$ disks (Laborclin ${ }^{\circledR}$, Paraná, Brazil) were deposited, and the plates were incubated at $35 \pm 2^{\circ} \mathrm{C}$ for $24 \mathrm{~h}$ for further analysis of the results by reading the inhibition halos using the CLSI cutoff points [14]. CoPS were considered resistant to CTX, TEC, and VAN when the inhibition halos were below 24, 16, and $17 \mathrm{~mm}$, respectively.

The microdilution test was performed to determine the minimum inhibitory concentration (MIC). Initially,
Müeller-Hinton broth was deposited in all wells of the microdilution plates. OXA or VAN (Sigma-Aldrich ${ }^{\circledR}$, Missouri, USA) was distributed through serial dilution, obtaining concentration ranged from 0.25 to $128 \mu \mathrm{g} / \mathrm{mL}$ and 0.0625 to $32 \mu \mathrm{g} / \mathrm{mL}$, respectively. The bacterial inoculums were adjusted to 0.5 of the McFarland scale, diluted, and deposited on the plates at the concentration of $10^{5} \mathrm{UFC} / \mathrm{mL}$. Finally, the plates were incubated at $35 \pm 2^{\circ} \mathrm{C}$ for $24 \mathrm{~h}$, and after incubation, the MIC was determined as the lowest concentration where there was no microbial growth. The susceptibility profile was determined through the CLSI cutoff points [14]. CoPS were considered resistant to OXA and VAN when the MICs were above 0.5 and $4 \mu \mathrm{g} / \mathrm{mL}$, respectively.

In the agar screening for OXA and VAN, initially, they prepared plates containing $\mathrm{MHA}, 4 \% \mathrm{NaCl}$, and $6 \mu \mathrm{g} / \mathrm{mL}$ of OXA and plates containing brain heart infusion agar (BHIA) (HiMedia ${ }^{\circledR}$, Mumbai, India) and $6 \mu \mathrm{g} / \mathrm{mL}$ of VAN. Then, the inoculums of the microorganisms were adjusted to 0.5 of the McFarland scale and seeded in the plates. Subsequently, the plates were incubated at $35 \pm 2{ }^{\circ} \mathrm{C}$ for $24 \mathrm{~h}$, and after incubation, the plates were observed against the light for observation of bacterial growth. Any growth after 24 hours of incubation was considered resistant to OXA and/or VAN [14].

\subsubsection{Antimicrobial Susceptibility Tests of Enterobacteriaceae.} The identification of the resistance profile of Enterobacteriaceae was carried out according to the Clinical and Laboratory Standards Institute [14]. The tests used in this study were the disk diffusion method, approximation test, and Hodge test.

In the disk diffusion method, the inoculums of the microorganisms were adjusted to 0.5 of the McFarland scale and seeded onto plates containing MHA. The ceftazidime (CAZ) $(30 \mu \mathrm{g})$, CTX $(30 \mu \mathrm{g})$, cefpodoxime (CPD) $(10 \mu \mathrm{g})$, aztreonam (ATM) $(30 \mu \mathrm{g})$, imipenem (IMP) $(10 \mu \mathrm{g})$, and meropenem (MEM) $(10 \mu \mathrm{g})$ disks (Laborclin ${ }^{\circledR}$, Paraná, Brazil) were deposited, and the plates were incubated at $35 \pm 2^{\circ} \mathrm{C}$ for $24 \mathrm{~h}$ for further analysis of the results by reading the inhibition halos using the CLSI cutoff points [14]. The approximation and Hodge tests were performed with the resistant strains in the disk diffusion method.

The approximation test was performed to determine the ESBL. Initially, the inoculums of the microorganismswere adjusted to 0.5 of the McFarland scale and seeded onto plates containing MHA. Thereafter, the amoxicillin/clavulanic acid (AMC) $(10 \mu \mathrm{g})$ disk (Laborclin ${ }^{\circledR}$, Paraná, Brazil) was added in the center of the plates, and ATM and CAZ disks have been added with a distance of 20 to $25 \mathrm{~mm}$ from the AMC, on the sides of the plate. The plates were incubated at $35 \pm 2^{\circ} \mathrm{C}$ for $24 \mathrm{~h}$, and it was analyzed if there was an increase in the diameter of the inhibition halo or the appearance of the phantom zone, distortion of the halo around the $\beta$-lactam disk [14].

The Hodge test was performed to determine the KPCproducing bacteria. Initially, Escherichia coli ATCC 25922 was adjusted to 0.5 of the McFarland scale and seeded onto 
plates containing MHA. In the center of the plates was added a MEM disk. Subsequently, with the help of a handle, samples tests were striated near the $\beta$-lactam disk. The plates were incubated at $35 \pm 2^{\circ} \mathrm{C}$ for $24 \mathrm{~h}$, and it was analyzed for the presence of distortion in the inhibition halo, which is indicative of carbapenemase production [14].

2.6.3. Antifungal Susceptibility Testing for Yeasts. Reference microdilution trays, containing serial drug dilutions, were prepared by following the CLSI M27-A3 guidelines [15]. Initially, the RPMI 1640 medium (SigmaAldrich ${ }^{\circledR}$, Missouri, USA) was buffered to $\mathrm{pH} 7.0$ with $0.165 \mathrm{M}$ of morpholinopropanesulphonic acid (MOPS) (Sigma-Aldrich ${ }^{\circledR}$, Missouri, USA).

In order to obtain a yeast inoculum containing $1-5 \times 10^{6} \mathrm{CFU} / \mathrm{mL}$, each strain was cultured on a tube containing $20 \mathrm{~mL}$ of Sabouraud dextrose agar (SDA) (HiMedia ${ }^{\circledR}$, Mumbai, India) plus yeast extract at $35^{\circ} \mathrm{C}$ for $24 \mathrm{~h}$ for Candida, Rhodotorula, and Trichosporon isolates and $48 \mathrm{~h}$ for Cryptococcus isolates. After this time, yeast suspensions were prepared in sterile physiological solution $(0.85 \%)$ and maintained at $28 \pm 2^{\circ} \mathrm{C}$ and then were adjusted to $90 \%$ transmittance at $530 \mathrm{~nm}$. Two serial dilutions from 1 : 100 and 1:20 sequentially were made to obtain a final inoculum containing $0.5 \times 10^{3}$ to $2.5 \times 10^{3} \mathrm{CFU} / \mathrm{mL}$. The reference strain Candida parapsilosis ATCC 22019 was used. The standard antifungal drugs used were fluconazole (Pfizer Inc., New York, USA) and amphotericin B (Bristol-Myers Squibb, Princeton, USA). These drugs were dissolved in deionized water and dimethylsulfoxide, respectively, and tested in concentration ranged from 0.0312 to $64 \mu \mathrm{g} / \mathrm{mL}$.

The microplates were incubated at $35^{\circ} \mathrm{C}$ in a non- $\mathrm{CO}_{2}$ incubator and were visually evaluated after $48 \mathrm{~h}$. The MIC corresponded to the lowest drug dilution that showed growth inhibition at least $50 \%$ when compared to untreated yeasts for fluconazole and that completely growth inhibited when compared to untreated inoculum for amphotericin B. The tests were performed in duplicate.

\subsection{Evaluation of Biofilm Production in Bacteria and Yeasts}

2.7.1. Congo Red Agar Test. The qualitative determination of biofilm production by bacterial and fungal isolates was performed according to the red Congo agar method $[16,17]$. Bacterial and fungal isolates were adjusted to 0.5 of the McFarland scale $\left(10^{8} \mathrm{CFU} / \mathrm{mL}\right)$ in BHIB, incubated at $35 \pm 2^{\circ} \mathrm{C}$ for $24 \mathrm{~h}$, and seeded on plates containing red Congo agar medium (HiMedia ${ }^{\circledR}$, Mumbai, India). Subsequently, they were incubated in an aerobic environment at $35 \pm 2^{\circ} \mathrm{C}$ for $48 \mathrm{~h}$. After this period, the colonies that presented blackish coloration, with dry or rough consistency, were considered as biofilm producers. Red colonies with mucosal consistency were considered as non-biofilm producers.

2.7.2. Crystal Violet Staining Method. The quantification of biofilm production by bacteria and yeasts was performed by the crystal violet staining method reported by Stepanovié et al. [18] and Marcos-Zambrano et al. [19], respectively. For bacterial biofilm production, the bacteria were adjusted in tryptone soybean broth (TSB) (HiMedia ${ }^{\circledR}$, Mumbai, India) supplemented with $1 \%$ glucose in the $0.5 \mathrm{McF}$ arland scale $\left(10^{8} \mathrm{CFU} / \mathrm{mL}\right)$ and distributed in microdilution plates. For fungal biofilm production, the yeasts were adjusted in RPMI 1640 medium on the $0.5 \mathrm{McF}$ arland scale $\left(10^{6} \mathrm{CFU} / \mathrm{mL}\right)$ and distributed in microdilution plates. The microplates of bacteria and fungi were incubated at $35 \pm 2^{\circ} \mathrm{C}$ for $48 \mathrm{~h}$. After incubation, the supernatant was removed, and the wells were washed with phosphate buffer $\mathrm{pH} 7.4$. Then, $200 \mu \mathrm{L}$ of $99 \%$ methanol was added for 15 minutes, and then the wells were emptied. Subsequently, the crystal violet (Sigma-Aldrich ${ }^{\circledR}$, Missouri, USA) was added to the plates, which were incubated at $37^{\circ} \mathrm{C}$ for $30 \mathrm{~min}$. Thereafter, the contents of the wells were removed, and the wells were washed with phosphate buffer and glacial acetic acid was added. Finally, the optical density (OD) was measured by spectrophotometry at $570 \mathrm{~nm}$ (Multiskan microplate photometer FC, Thermo scientific, Madrid, Spain).

Wells containing only culture medium were used as controls. The strains were classified into four categories based on the OD values of the biofilms compared to ODc (optical density of control). The strains were classified as nonadherent if $\mathrm{OD} \leq \mathrm{ODc}$; poor yield if $\mathrm{ODc}<\mathrm{OD}$ $\leq 2 \times \mathrm{ODc}$; moderate production if $2 \times \mathrm{ODc}<\mathrm{OD} \leq 4 \times \mathrm{ODc}$; or strong production if $4 \times \mathrm{ODc}<\mathrm{OD}$ [14].

\section{Results}

3.1. Identification and Characterization of Antimicrobial Resistance Profile and Biofilm Production of CoPS. CoPS was identified in eight (67\%) of the 12 birds analyzed, represented by all specimens of $R$. magnirostris and two specimens of C. plancus (Table 1). Regarding the antimicrobial resistance profiles analyzed, the concomitant profile MRand VR-CoPS were identified in 50\% of the samples; only the profile MR-CoPS was present in $12.5 \%$, and $37.5 \%$ of the CoPS isolated from the oropharynx of the birds was antibiotic-sensitive. Considering the presence of these bacteria in the R. magnirostris specimens, it was identified that an incidence of $50 \%$ of antibiotic-sensitive CoPS, $33 \%$ of MR, and VR-CoPS concurrently and $17 \%$ of only MR-CoPS. While in the C. plancus, VR-CoPS strains were present in $100 \%$ of the samples (Table 1).

Regarding the biofilm production, the results of the qualitative method using the Congo red agar were faithful to the results of the quantitative method performed by the violet crystal staining. Among the 8 CoPS isolates, 3 were biofilm producers in the qualitative method (37.5\%) (Figure 1). From the data of the quantitative method, it was possible to observe that of these 3 isolates that were biofilm producers, 2 isolates were weak biofilm producers (66.7\%) and one isolate was strong a biofilm producer (33.3\%). In the $R$. magnirostris specimens, $67 \%$ of the samples was considered as nonbiofilm producers, $17 \%$ as strong producers, and $16 \%$ as weak producers. On the other hand, in the $C$. plancus specimens, $50 \%$ of the samples was weak biofilm producers and the other $50 \%$ was strong producers (Table 1 ). 
TABLE 1: Resistance profile and biofilm production of coagulase-positive staphylococci isolated from oropharynx of Rupornis magnirostris and Caracara plancus.

\begin{tabular}{|c|c|c|c|c|c|c|c|c|c|c|}
\hline \multirow[t]{2}{*}{ Animals } & \multicolumn{2}{|c|}{ Screening } & \multicolumn{2}{|c|}{$\begin{array}{l}\text { Microdilution } \\
(\mathrm{MIC} \mu \mathrm{g} / \mathrm{mL})\end{array}$} & \multicolumn{3}{|c|}{$\begin{array}{c}\text { Disk diffusion } \\
\text { (inhibition zone } \mathrm{mm} \text { ) }\end{array}$} & \multirow[t]{2}{*}{ Resistance profile } & \multicolumn{2}{|c|}{ Biofilm production } \\
\hline & OXA & VAN & OXA & VAN & CTX & TEC & VAN & & Congo red & Crystal violet \\
\hline Rupornis magnirostris 1 & - & - & 1 & 0.5 & $28.2 \pm 2.2$ & $20.4 \pm 2.2$ & $24.6 \pm 1.2$ & Antibiotic-sensitive CoPS & - & Nonproducer \\
\hline Rupornis magnirostris 2 & + & + & $>128$ & $>32$ & $15.4 \pm 1.9$ & 0 & 0 & MR- and VR-CoPS & + & Weak \\
\hline Rupornis magnirostris 3 & - & - & 1 & 0.5 & $32.8 \pm 1.3$ & $21.9 \pm 2.1$ & $24.2 \pm 0.4$ & Antibiotic-sensitive CoPS & - & Nonproducer \\
\hline Rupornis magnirostris 4 & + & - & 128 & 0.5 & $16.2 \pm 0.5$ & $23.1 \pm 1.2$ & $23.0 \pm 0.9$ & MR-CoPS & - & Nonproducer \\
\hline Rupornis magnirostris 5 & - & - & $\leq 0.25$ & 0.5 & $28.4 \pm 1.0$ & $21.5 \pm 1.6$ & $24.7 \pm 1.4$ & Antibiotic-sensitive CoPS & - & Nonproducer \\
\hline Rupornis magnirostris 6 & + & + & $>128$ & $>32$ & $14.7 \pm 1.3$ & 0 & 0 & MR and VR-CoPS & + & Strong \\
\hline Caracara plancus 1 & + & + & $>128$ & $>32$ & $13.0 \pm 0.5$ & 0 & 0 & MR and VR-CoPS & + & Weak \\
\hline Caracara plancus 2 & + & + & $>128$ & $>32$ & $13.9 \pm 0.8$ & 0 & 0 & MR and VR-CoPS & - & Nonproducer \\
\hline
\end{tabular}

MIC: minimum inhibitory concentration; OXA: oxacillin; VAN: vancomycin; CTX: cefoxitin; TEC: teicoplanin; and CoPS: coagulase-positive staphylococci.

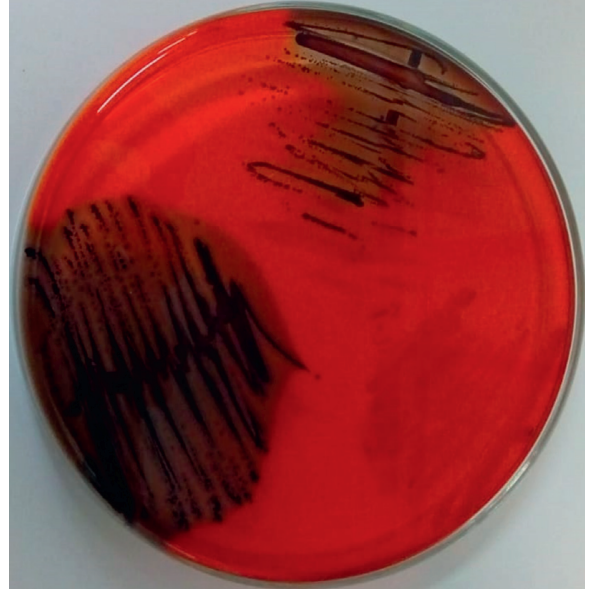

FIGURE 1: Biofilm production by coagulase-positive staphylococci isolated from the oropharynx of Rupornis magnirostris and $\mathrm{Ca}$ racara plancus by the red Congo agar method after 24 hours at $35^{\circ} \mathrm{C}$.

\subsection{Identification and Characterization of Antimicrobial Resistance Profile and Biofilm Production of} Enterobacteriaceae. Nine animals had enterobacteria $(75 \%)$, including all specimens of $R$. magnirostris and three birds of the $C$. plancus. Twenty-seven species of enterobacteria were isolated, and in all the animals, the co-occurrence of two to four different species was identified. The most frequently isolated pathogen was Escherichia coli (25\%), isolated from 6 animals, followed by Salmonella spp. (25\%), Klebsiella oxytoca (15\%), and Proteus mirabilis (15\%) identified in four animals. Besides Shigella spp. (10\%) and Klebsiella pneumoniae (10\%) isolated from three animals (Table 2).

Related to the antimicrobial resistance profile, of the 27 enterobacteria isolated from the animals, 14 strains were antibiotic-sensitive enterobacteria (51.9\%), 8 strains were extended-spectrum beta-lactamase-producing Enterobacteriaceae (ESBL) (29.6\%), 3 isolates were third-generation cephalosporins-resistant Salmonella spp. (11.1\%), and 2 isolates were KPC-producing bacteria (7.4\%). The results for each species showed the presence of $22.2 \%, 11.1 \%$, and $11.1 \%$ of the ESBL, third-generation cephalosporins-resistant Salmonella spp., and KPC, respectively, in the 18 samples from $R$. magnirostris, while in the 9 bacteria isolated from C. plancus, $44.4 \%$ was ESBL and $11.1 \%$ was third-generation cephalosporins-resistant Salmonella spp. (Table 2).

Regard to the biofilm production, 16 from the 27 isolates of enterobacteria were biofilm producers in the qualitative method (59\%). It was possible to observe that of these 16 biofilm-producing isolates, 4 isolates were weak producers (25\%) and 12 isolates were strong biofilm producers (75\%). Taking into account the analyzed species, it was identified that $37 \%$ of the samples from R. magnirostris specimens was not biofilm producers, 5\% were weak producer, and 58\% were moderate biofilm producers. While in the $C$. plancus specimens, $50 \%$ of the samples was identified as nonbiofilm producers, $37 \%$ was weak producer, and $13 \%$ was moderate biofilm producers (Table 2).

\subsection{Identification and Characterization of Antimicrobial} Resistance Profile and Biofilm Production of Yeasts. Yeasts were identified in 7 of the 12 animals (58.3\%), being represented by 4 animals of the $R$. magnirostris specimens and 3 of the $C$. plancus specimens, totalizing 10 yeast isolates. Among these 10 yeasts, 2 were identified as Candida metapsilosis (20\%), 2 were Rhodotorula mucilaginosa (20\%), 2 were Trichosporon coremiiform (20\%), 1 was Rhodotorula glutinis (10\%), 1 was Cryptococcus sp. (10\%), 1 was Candida sp. (10\%), and 1 was Candida ciferri (10\%) (Table 3).

Regarding the susceptibility profile of yeast isolates, it was possible to observe that Rhodotorula mucilaginosa isolates showed resistance to fluconazole and susceptibility to amphotericin B. However, the isolates of Trichosporon coremiiform showed resistance to amphotericin $\mathrm{B}$ and susceptibility to fluconazole. Candida metapsilosis, Candida ciferri, and Rhodotorula glutinis showed dose-dependent susceptibility to fluconazole but were susceptible to amphotericin B (Table 3).

As for the biofilm production, of the 10 yeast isolates, 7 were biofilm producers (70\%), and all were classified as weak biofilm producers (100\%). The R. magnirostris specimens had $83 \%$ of biofilm former and $17 \%$ of nonformer specimens, whereas C. plancus presented $50 \%$ of weak biofilm producer samples and the other $50 \%$ had no biofilm producer ability (Table 3 ). 
TABLE 2: Resistance profile and biofilm production of Enterobacteriaceae isolated from oropharynx of Rupornis magnirostris and Caracara plancus.

\begin{tabular}{|c|c|c|c|c|c|c|c|c|c|c|c|c|}
\hline \multirow[b]{2}{*}{ Animals } & \multirow{2}{*}{$\begin{array}{c}\text { Bacteria } \\
\text { identifications }\end{array}$} & \multicolumn{6}{|c|}{ Inhibition zone (mm) } & \multirow{2}{*}{$\begin{array}{l}\text { Approximation } \\
\text { test }\end{array}$} & \multirow{2}{*}{$\begin{array}{l}\text { Hodge } \\
\text { test }\end{array}$} & \multirow{2}{*}{$\begin{array}{l}\text { Resistance } \\
\text { profile }\end{array}$} & \multicolumn{2}{|c|}{ Biofilm production } \\
\hline & & CAZ & CTX & $\mathrm{CPD}$ & ATM & IMP & MEM & & & & $\begin{array}{l}\text { Congo } \\
\text { red }\end{array}$ & Crystal violet \\
\hline \multirow{4}{*}{$\begin{array}{l}\text { Rupornis } \\
\text { magnirostris } 1\end{array}$} & $\begin{array}{l}\text { Salmonella } \\
\text { spp. }\end{array}$ & $\mathrm{S}$ & $\mathrm{S}$ & $\mathrm{S}$ & $\mathrm{S}$ & $\mathrm{S}$ & $\mathrm{S}$ & NP & NP & NR & + & Moderate \\
\hline & $\begin{array}{c}\text { Klebsiella } \\
\text { oxytoca }\end{array}$ & S & S & S & S & S & S & NP & NP & NR & + & Weak \\
\hline & Shigella spp. & $S$ & $\mathrm{~S}$ & $S$ & S & $S$ & S & NP & NP & NR & - & Nonproducer \\
\hline & $\begin{array}{l}\text { Proteus } \\
\text { mirabilis }\end{array}$ & $\mathrm{R}$ & $\mathrm{R}$ & $\mathrm{R}$ & $\mathrm{R}$ & NP & $\mathrm{S}$ & + & - & ESBL & - & Nonproducer \\
\hline \multirow{3}{*}{$\begin{array}{l}\text { Rupornis } \\
\text { magnirostris } 2\end{array}$} & $\begin{array}{c}\text { Klebsiella } \\
\text { pneumoniae }\end{array}$ & $\mathrm{S}$ & S & $\mathrm{S}$ & S & $\mathrm{S}$ & $\mathrm{S}$ & NP & NP & NR & + & Moderate \\
\hline & $\begin{array}{c}\text { Escherichia } \\
\text { coli }\end{array}$ & $\mathrm{R}$ & $\mathrm{R}$ & $\mathrm{R}$ & $\mathrm{R}$ & S & S & + & - & ESBL & - & Nonproducer \\
\hline & $\begin{array}{l}\text { Salmonella } \\
\text { spp. }\end{array}$ & $\mathrm{R}$ & $\mathrm{R}$ & $\mathrm{R}$ & $\mathrm{R}$ & $S$ & $S$ & + & - & $\begin{array}{c}\text { Third- } \\
\text { generation } \\
\text { cephalosporins }\end{array}$ & + & Moderate \\
\hline \multirow{3}{*}{$\begin{array}{l}\text { Rupornis } \\
\text { magnirostris } 3\end{array}$} & $\begin{array}{l}\text { Salmonella } \\
\text { spp. }\end{array}$ & S & S & S & $S$ & S & S & NP & NP & NR & + & Moderate \\
\hline & $\begin{array}{l}\text { Klebsiella } \\
\text { oxytoca }\end{array}$ & $\mathrm{R}$ & $\mathrm{R}$ & $\mathrm{R}$ & $\mathrm{R}$ & $\mathrm{R}$ & $\mathrm{R}$ & - & + & KPC & + & Moderate \\
\hline & $\begin{array}{c}\text { Escherichia } \\
\text { coli }\end{array}$ & $\mathrm{R}$ & $\mathrm{R}$ & $\mathrm{R}$ & $\mathrm{R}$ & $\mathrm{R}$ & $\mathrm{R}$ & - & + & KPC & - & Nonproducer \\
\hline \multirow{3}{*}{$\begin{array}{l}\text { Rupornis } \\
\text { magnirostris } 4\end{array}$} & $\begin{array}{c}\text { Escherichia } \\
\text { coli }\end{array}$ & S & $\mathrm{S}$ & S & S & S & S & NP & NP & NR & - & Nonproducer \\
\hline & $\begin{array}{l}\text { Salmonella } \\
\text { spp. }\end{array}$ & $\mathrm{S}$ & $\mathrm{S}$ & $\mathrm{S}$ & S & $\mathrm{S}$ & S & NP & NP & NR & + & Moderate \\
\hline & $\begin{array}{l}\text { Proteus } \\
\text { mirabilis }\end{array}$ & S & $\mathrm{S}$ & $\mathrm{S}$ & S & NP & $\mathrm{S}$ & NP & NP & NR & - & Nonproducer \\
\hline \multirow{3}{*}{$\begin{array}{l}\text { Rupornis } \\
\text { magnirostris } 5\end{array}$} & $\begin{array}{l}\text { Salmonella } \\
\text { spp. }\end{array}$ & $\mathrm{S}$ & $\mathrm{S}$ & S & S & S & $S$ & NP & NP & NR & + & Moderate \\
\hline & $\begin{array}{c}\text { Klebsiella } \\
\text { pneumoniae }\end{array}$ & $\mathrm{S}$ & $\mathrm{S}$ & S & S & S & S & NP & NP & NR & + & Moderate \\
\hline & $\begin{array}{l}\text { Proteus } \\
\text { mirabilis }\end{array}$ & $\mathrm{R}$ & $\mathrm{R}$ & $\mathrm{R}$ & $\mathrm{R}$ & NP & $S$ & + & - & ESBL & - & Nonproducer \\
\hline \multirow{3}{*}{$\begin{array}{l}\text { Rupornis } \\
\text { magnirostris } 6\end{array}$} & Shigella spp. & $\mathrm{R}$ & $\mathrm{R}$ & $\mathrm{R}$ & $\mathrm{R}$ & $S$ & S & + & - & ESBL & + & Moderate \\
\hline & $\begin{array}{l}\text { Salmonella } \\
\text { spp. }\end{array}$ & $\mathrm{R}$ & $\mathrm{R}$ & $\mathrm{R}$ & $\mathrm{R}$ & $\mathrm{S}$ & $\mathrm{S}$ & + & - & $\begin{array}{l}\text { Ihird- } \\
\text { generation } \\
\text { cephalosporins }\end{array}$ & + & Moderate \\
\hline & $\begin{array}{c}\text { Escherichia } \\
\text { coli }\end{array}$ & $\mathrm{R}$ & $\mathrm{R}$ & $\mathrm{R}$ & $\mathrm{R}$ & S & S & + & - & ESBL & + & Moderate \\
\hline \multirow{2}{*}{$\begin{array}{l}\text { Caracara } \\
\text { plancus } 2\end{array}$} & $\begin{array}{l}\text { Salmonella } \\
\text { spp. }\end{array}$ & $\mathrm{R}$ & $\mathrm{R}$ & $\mathrm{R}$ & $\mathrm{R}$ & $S$ & S & + & - & $\begin{array}{c}\text { Third- } \\
\text { generation } \\
\text { cephalosporins }\end{array}$ & + & Moderate \\
\hline & $\begin{array}{c}\text { Escherichia } \\
\text { coli }\end{array}$ & S & $\mathrm{S}$ & $\mathrm{S}$ & S & $\mathrm{S}$ & S & NP & NP & NR & - & Nonproducer \\
\hline \multirow{3}{*}{$\begin{array}{l}\text { Caracara } \\
\text { plancus } 4\end{array}$} & $\begin{array}{c}\text { Klebsiella } \\
\text { oxytoca }\end{array}$ & $\mathrm{R}$ & $\mathrm{R}$ & $\mathrm{R}$ & $\mathrm{R}$ & S & $\mathrm{S}$ & + & - & ESBL & - & Nonproducer \\
\hline & $\begin{array}{c}\text { Klebsiella } \\
\text { pneumoniae }\end{array}$ & $\mathrm{R}$ & $\mathrm{R}$ & $\mathrm{R}$ & $\mathrm{R}$ & $S$ & S & + & - & ESBL & + & Weak \\
\hline & $\begin{array}{c}\text { Proteus } \\
\text { mirabilis }\end{array}$ & S & S & S & $S$ & NP & S & NP & NP & NR & + & Weak \\
\hline \multirow{3}{*}{$\begin{array}{l}\text { Caracara } \\
\text { plancus } 5\end{array}$} & Shigella spp. & $\mathrm{S}$ & $\mathrm{S}$ & $\mathrm{S}$ & $\mathrm{S}$ & $\mathrm{S}$ & $\mathrm{S}$ & NP & NP & NR & - & Nonproducer \\
\hline & $\begin{array}{c}\text { Escherichia } \\
\text { coli }\end{array}$ & $\mathrm{R}$ & $\mathrm{R}$ & $\mathrm{R}$ & $\mathrm{R}$ & S & $\mathrm{S}$ & + & - & ESBL & - & Nonproducer \\
\hline & $\begin{array}{c}\text { Klebsiella } \\
\text { oxytoca }\end{array}$ & S & $S$ & S & S & S & S & NP & NP & NR & + & Weak \\
\hline
\end{tabular}

S: sensible; R: resistant; NR: no resistance; NP: not performed; CAZ: ceftazidime; CTX: cefoxitin; CPD: cefpodoxime; ATM: aztreonam; IMP: imipenem; MEM: meropenem; ESBL: extended-spectrum $\beta$-lactamase-(ESBL-) producing Enterobacteriaceae; and KPC: Klebsiella pneumoniae carbapenemase. 
TABLE 3: Resistance profile and biofilm production of yeasts isolated from oropharynx of Rupornis magnirostris and Caracara plancus.

\begin{tabular}{|c|c|c|c|c|c|c|c|}
\hline \multirow{2}{*}{ Animals } & \multirow{2}{*}{ Identification of species } & \multirow{2}{*}{$\begin{array}{l}\mathrm{MIC}_{\mathrm{AmB}} \\
(\mu \mathrm{g} / \mathrm{mL})\end{array}$} & \multirow{2}{*}{ Susceptibility } & \multirow{2}{*}{$\begin{array}{l}\mathrm{MIC}_{\mathrm{FLU}} \\
(\mu \mathrm{g} / \mathrm{mL})\end{array}$} & \multirow{2}{*}{ Susceptibility } & \multicolumn{2}{|c|}{ Biofilm production } \\
\hline & & & & & & Congo red & Crystal violet \\
\hline Rupornis magnirostris 1 & Candida metapsilosis & 0.25 & S & 0.50 & $S$ & + & Weak \\
\hline \multirow[t]{2}{*}{ Rupornis magnirostris 2} & Rhodotorula mucilaginosa & 1 & S & 64 & $\mathrm{R}$ & + & Weak \\
\hline & Candida metapsilosis & 0.125 & S & 1 & S & - & Nonproducer \\
\hline \multirow[t]{2}{*}{ Rupornis magnirostris 3} & Candida sp. & 0.06 & S & 2 & S & + & Weak \\
\hline & Cryptococcus sp. & 0.50 & $S$ & 4 & $S$ & + & Weak \\
\hline Rupornis magnirostris 5 & Rhodotorula mucilaginosa & 1 & S & 64 & $\mathrm{R}$ & + & Weak \\
\hline Caracara plancus 1 & Candida ciferri & 1 & S & 16 & SDD & + & Weak \\
\hline \multirow{2}{*}{ Caracara plancus 2} & Rhodotorula glutinis & 0.50 & S & 32 & SDD & - & Nonproducer \\
\hline & Trichosporon coremiiforme & 4 & $\mathrm{R}$ & 0.0125 & S & - & Nonproducer \\
\hline Caracara plancus 3 & Trichosporon coremiiforme & 4 & $\mathrm{R}$ & 0.06 & $S$ & + & Weak \\
\hline
\end{tabular}

$\mathrm{MIC}_{\mathrm{AmB}}$ : minimum inhibitory concentration of amphotericin B; MIC $\mathrm{FLU}$ : minimum inhibitory concentration of fluconazole; S: susceptible; R: resistant; SDD: susceptible dose-dependent; +: producer of biofilm; and -: nonproducer of biofilm.

\section{Discussion}

We highlight that the study of dissemination of biofilmforming microorganisms with an antimicrobial resistance profile is of interest to human and animal health [9]. In this context, the identification of these pathogens in animals, such as birds, is very relevant.

Recent studies have also identified Staphylococcus spp. in birds. Dipineto et al. [20] identified the presence of $87.7 \%$ of $S$. aureus in bacterial isolates from birds of prey. Concerning antimicrobial resistant $S$. aureus samples, other studies have already isolated these bacteria in several anatomical sites of wild birds. Loncaric et al. [5] also identified isolates of Staphylococcus aureus with resistance to methicillin in faecal samples from a migratory population of Corvus frugilegus and suggest that these genotypes originated from humans and cattle, but were disseminated affecting wild organisms.

The reports of VR-CoPS identification in birds are scarce, since vancomycin is used in a limited way in treatments of some infections. However, isolates of VR-CoPS have been previously reported in birds at Brazil, being the first report of resistance to this antimicrobial carried out by Martins et al. [21]. These authors also describe the presence of both van $\mathrm{A}$ and $v a n \mathrm{~B}$ genes in all vancomycin-resistant isolates. Therefore, it is possible to state that there is already an unusual description of Staphylococcus spp. with resistance to vancomycin in birds at Brazil. In our study, $50 \%$ of CoPS isolates were VR-CoPS. Resistance to vancomycin also occurs in other species of the genus Staphylococcus, as reported in the study developed by Ishihara et al. [22] that identified biofilmforming Staphylococcus succinus with vancomycin resistance genes isolated from saliva of wild songbirds.

Data related to avian biofilm-forming VR-CoPS are also rare; among the few studies, we emphasize the study of Nemati et al. [23] that identified genes associated with biofilm production in $S$. aureus isolates from the nostrils, skin, cloaca of healthy animals, and head injuries of poultry farms.

Enterobacteria were a group of bacteria that can be part of the intestinal microbiota of animals; nevertheless, this microbiota can develop the ability to cause gastrointestinal infections and damages the enteric area of humans and animals [20].

Several studies have reported the presence of enterobacteria, such as E. coli, Salmonella spp., Klebsiella spp., Proteus spp., and Shigella spp., in anatomical sites of birds of prey, such as cloacal samples of gavião-carijó, cloacal and pharyngeal samples of the griffon vulture (Gyps fulvus), cloaca samples of hawk-carijó, and faecal samples from resident and migratory population of rooks (Corvus frugilegus), in several countries around the world $[5,8,18$, 20, 24-26].

Enterobacteriaceae family with antimicrobial resistance profiles is considered a public health threat due to their zoonotic potential [5]. Micro-organisms of the ESBL-producing Enterobacteriaceae family found in free-living animals have been reported, mostly in birds. Although several bacteria from the Enterobacteriaceae group presented this resistance profile, ESLB was more frequently identified in $E$. coli followed by K. pneumoniae [27]. Loncaric et al. [5] identified ESBL Enterobacteriaceae isolates in faecal samples from resident and migratory population of rooks (Corvus frugilegus) in Austria.

Klebsiella pneumoniae carbapenemase (KPC) are the most common class A carbapenemases and are mostly encoded by $K$. pneumoniae enzymes. In humans, infections associated with the KPC profile tend to present systemic conditions, causing serious clinical conditions that are difficult to treat due to limited antibiotic options [28]. Regarding the identification of KPC-producing bacteria in animals, the data in the literature are scarce and restricted to domestic animals, such as the study of Stolle et al. [29] that identified this profile in dogs.

Some species of the family Enterobacteriaceae are known to produce biofilm, including E. coli and Salmonella spp. In the study performed by Olson et al. [30], E. coli biofilms isolated from poultry, swine, and cattle were resistant to most of the antimicrobials analyzed. In the study performed by Nandanwar et al. [31], the results showed that the isolated pathogenic E. coli strains from birds and mammals were able 
to form biofilms, besides being resistant to the bactericidal activity of human and avian sera, highlighting the potential zoonotic risk.

Some studies indicate the presence of biofilm-producing Enterobacteriaceae in breeding birds and by-products. Chuah et al. [32] analyzed enteric strains of Salmonella species from samples of birds and environmental samples collected from wet-markets in northern Malaysia. In this study, all strains were biofilm-producing, and $69.3 \%$ of them were strong biofilm producers. Studies that analyze the presence of Salmonella spp. consider this biofilm as a source of constant contamination of poultry production systems, generating economic and public health impacts [33].

Several species of yeast are pathogenic to humans and animals, including free-living birds. Thus, the present study was linear with the previous study, which reported the presence of Rhodotorula spp., Cryptococcus spp., and Trichosporon spp. isolated in samples from birds, such as pigeons, passeriform feces samples in captivity, or samples of pappus lesions [34-37]. Representatives of the genus Candida cause candidiasis, a pathology that usually affects cutaneous and mucosal regions, as well as genital and gastrointestinal tract of animals and humans. In birds, there are reports of candidiasis mainly affecting the upper digestive system, with emphasis on the oropharynx and esophagus [38]. In a study with birds of prey, Samour and Naldo [38] identified candidiasis through clinical signs and positive cultures for C. albicans.

Mendes et al. [39] also shown the presence of some fungal strains in their analyzes in wild bird feces, reporting the presence of Candida spp., Trichosporon asahii, Rhodotorula sp., and Cryptococcus laurentii. Resistance to antimicrobial agents in yeasts isolated from birds has been described in the literature. Lord et al. [34] also identified resistance yeasts, such as C. albicans, C. laurentii, T. pullulans, $R$. rubra, and $R$. glutinis, in faecal samples from wild birds, and Costa et al. [35] identified strains of resistant Cryptococcus spp. in faecal samples of pigeons.

The most relevant results observed in this study and a matter of serious concern was the concomitant presence of micro-organisms with resistance profile and biofilm producers, such as 1MR- and VR-CoPS strains are strong producers of biofilm, 2 ESBL, 3 third-generation cephalosporins-resistant Salmonella spp., and 1 KPC strains are moderate producers of biofilm, 1 ESBL strain is a weak producer of biofilm, 1 Trichosporon coremiiforme strain is resistant to amphotericin B and a weak producer of biofilm, and 2 Rhodotorula mucilaginosa strains are resistant to fluconazole and are weak producers of biofilm.

Furthermore, the animals surveyed were in a Wild Animals Triage Center of the Environment agency of the Pernambuco state responsible for the care of local fauna. Thus, as in other studies, these animals come to be screened for complaints, accidents, and criminal capture and may be subsequently screened, kept in captivity for treatment and rehabilitation and for subsequent environmental reintegration, and some may remain in this center because they are not physically able to return to the natural environment $[40,41]$.
Since the collection of samples from the animals was performed before they were submitted to antibiotic therapy, we believe that the isolated micro-organisms actually emerged to microbiota of these animals and bring a close panorama of what contact they had in the natural environment where they lived before their capture. The space in which the animals were found was shared, including healthy animals, ready for environmental reintegration, sick and injured animals, as well as mutilated animals that remain in the screening center, which generates a potential for contamination between them. We emphasize that Rupornis magnirostris and Caracara plancus are well adapted to urban environments, especially Caracara plancus [42]. So these animals may have been contaminated by the environment and may have transmitted these pathogens among other animals that also returned to the natural environment, indicating that these bird of prey can be potential carriers and disseminators of resistant microorganismss and/or biofilm producers to other environments, other animals, and in humans, causing infections that are considered public health problem because all these bacteria are human pathogens that play an important role in drug resistance dissemination and potentialize several serious human infections, including septicemia and death [43-45]. In accordance with other studies, we also alert to the appropriate use of antibiotics in agriculture, livestock, veterinary medicine, and human medicine, avoiding the risk of the spread of zoonotic infections caused by drug-resistant microorganisms[46, 47].

A very probable hypothesis that explains the presence of resistant and/or biofilm-producing microorganismsin the birds of the present study is the fact that, in Brazil, laws regulate the production of medicines by pharmaceutical companies, but there is a lack of effective surveillance regarding the disposal of medicines. Thus, these medicines can reach the environment due to their incorrect disposal by the final consumer, who often discards these drugs directly in the garbage, or due to the untreated industrial waste [48]. Therefore, it is important to encourage studies to discover cross-transmission from animal to human and vice versa, and the role of the environment in this process.

\section{Conclusion}

Bearing in mind all these findings, the results of this study are relevant and significant as a preliminary study to emphasize the importance to fill the existing gap in veterinary medicine with regard to the identification of resistant microorganisms and biofilm producers in birds of prey species. Rupornis magnirostris and Caracara plancus have pathogenic micro-organisms of interest for human public health, such as CoPS, enterobacteria, and yeasts, in addition to species with resistance profile to several antimicrobials and/ or with biofilm production capacity. Our findings highlight the potential of these birds as a reservoir of microorganisms, in addition to being able to indicate a possible dissemination of pathogens in the environmental, human, and animal health, due to the convergence between urban and wild habitats. 


\section{Data Availability}

The data used to support this study are included within the article and will be made available upon request.

\section{Conflicts of Interest}

The authors declare that they have no conflicts of interest.

\section{Acknowledgments}

F.A. Silva thanks the Coordination for the Improvement of Higher Level Personnel (CAPES) for an MSc scholarship.

\section{References}

[1] R. O. Bierregaard, P. Boesman, and G. M. Kirwan, "Roadside hawk (Rupornis magnirostris)," in Handbook of the Birds of the World Alive, J. Del Hoyo, A. Elliott, J. Sargatal, D. A. Christie, and E. De Juana, Eds., Lynx Edicions, Barcelona, Spain, 2017, https://www.hbw.com/node/53121.

[2] R. Tinajero, F. Barragán, and L. Chapa-Vargas, "Raptor functional diversity in scrubland-agricultural landscapes of northern-central-Mexican dryland environments," Tropical Conservation Science, vol. 10, pp. 1-18, 2017.

[3] P. Andreazz, M. P. M. Marcos, and E. S. Santiago, "A avifauna em duas areas de uma zona rural com remanescentes de mata atlantica no noroeste fluminense," REINPEC, vol. 2, no. 2, pp. 45-70, 2017.

[4] L. T. R. Da Silva, E. F. Oliveira Filho, T. H. Kunst et al., "Heavy metal concentrations in free-living southern caracaras $(\mathrm{Ca}-$ racara plancus) in the northeast region of Brazil," Acta Scientiae Veterinareae, vol. 45, pp. 1-8, 2017.

[5] I. Loncaric, G. L. Stalder, K. Mehinagic et al., "Comparison of ESBL and AmpC producing Enterobacteriaceae and methicillin-resistant Staphylococcus aureus (MRSA) isolated from migratory and resident population of rooks (Corvus frugilegus) in Austria," PLoS One, vol. 8, no. 12, Article ID e84048, 2013.

[6] H. Radhouani, P. Poeta, A. Gonçalves, R. Pacheco, R. Sargo, and G. Igrejas, "Wild birds as biological indicators of environmental pollution: antimicrobial resistance patterns of Escherichia coli and enterococci isolated from common buzzards (Buteo buteo)," Journal of Medical Microbiology, vol. 61, no. 6, pp. 837-843, 2012.

[7] M. Sousa, N. Silva, G. Igrejas et al., "Antimicrobial resistance determinants in staphylococcus spp. recovered from birds of prey in Portugal," Veterinary Microbiology, vol. 171, no. 3-4, pp. 436-440, 2014.

[8] E. F. D. A. Silva, J. F. S. D. Barros, K. B. Fraga, C. P. Magalhães, J. E. Garcia, and I. M. F. Cavalcanti, "Cloacal enterobacteria isolated from captive roadside hawks (Rupornis magnirostris, Gmelin, 1788) and their antimicrobial susceptibility profile," Brazilian Journal of Veterinary Research and Animal Science, vol. 53, no. 2, pp. 207-213, 2017.

[9] F. A. Silva, S. A. Palácio, J. E. Garcia, and I. M. F. Cavalcanti, "Dissemination of multidrug-resistant bacteria in birds," Approaches in Poultry, Dairy \& Veterinary Sciences, vol. 3, no. 4, pp. 1-3, 2018.

[10] C. W. Hall and T.-F. Mah, "Molecular mechanisms of biofilmbased antibiotic resistance and tolerance in pathogenic bacteria," FEMS Microbiology Reviews, vol. 41, no. 3, pp. 276-301, 2017.

[11] D. F. J. Brown, D. I. Edwards, P. M. Hawkey et al., "Guidelines for the laboratory diagnosis and susceptibility testing of methicillin-resistant Staphylococcus aureus (MRSA)," Journal of Antimicrobial Chemotherapy, vol. 56, no. 6, pp. 1000-1018, 2005.

[12] E. W. Koneman and A. S. Koneman, Diagnostico Microbiologico: Texto y Atlas en Color, Médica Panamericana, Porto Alegre, Brazil, 6th edition, 2008.

[13] R. Lima-Neto, C. Santos, N. Lima, P. Sampaio, C. Pais, and R. P. Neves, "Application of MALDI-TOF MS for requalification of a Candida clinical isolates culture collection," Brazilian Journal of Microbiology, vol. 45, no. 2, pp. 515-522, 2014.

[14] Clinical and Laboratory Standards Institute, Approved Standards M100-S22: Performance Standards for Antimicrobial Susceptibility Testing; Twenty-Fourth Informational Supplement, Clinical and Laboratory Standards Institute, Wayne, PA, USA, 2016.

[15] Clinical and Laboratory Standards Institute, Reference Method for Broth Dilution 473 Antifungal Susceptibility Testing of Yeasts: Approved Standard M27-A3, Clinical and Laboratory Standards Institute, Wayne, PA, USA, 2008.

[16] D. J. Freeman, F. R. Falkiner, and C. T. Keane, "New method for detecting slime production by coagulase negative staphylococci," Journal of Clinical Pathology, vol. 42, no. 8, pp. 872-874, 1989.

[17] S. Türkyılmaz and S. Kaynarca, "The slime production by yeasts isolated from subclinical mastitic cows," Acta Veterinaria Brno, vol. 79, no. 4, pp. 581-586, 2010.

[18] S. Stepanovié, D. Vukovic, I. Dakic, B. Savic, and M. SvabicVlahovi, "A modified microtiter-plate test for quantification of staphylococcal biofilm formation," Journal of Microbiological Methods, vol. 40, no. 2, pp. 175-179, 2000.

[19] L. J. Marcos-Zambrano, P. Escribano, E. Bouza, and J. Guinea, "Production of biofilm by candida and non-Candida spp. isolates causing fungemia: comparison of biomass production and the metabolic activity and development of cut-off points," International Journal of Medical Microbiology, vol. 304, no. 8, pp. 1192-1198, 2014.

[20] L. Dipineto, L. M. D. L. Bossa, A. Pace et al., "Microbiological survey of birds of prey pellets," Comparative Immunology, Microbiology and Infectious Diseases, vol. 41, pp. 49-53, 2015.

[21] P. D. Martins, T. T. De Almeida, A. P. Basso et al., "Coagulasepositive staphylococci isolated from chicken meat: pathogenic potential and vancomycin resistance," Foodborne Pathogens and Disease, vol. 10, no. 9, pp. 771-776, 2013.

[22] S. Ishihara, J. J. Bitner, G. H. Farley, and E. T. Gillock, "Vancomycin-resistant Gram-positive cocci isolated from the saliva of wild songbirds," Current Microbiology, vol. 66, no. 4, pp. 337-343, 2013.

[23] M. Nemati, K. Hermans, L. A. Devriese, D. Maes, and F. Haesebrouck, "Screening of genes encoding adhesion factors and biofilm formation in Staphylococcus aureus isolates from poultry," Avian Pathology, vol. 38, no. 6, pp. 513-517, 2009.

[24] A. Vidal, L. Baldomà, R. A. Molina-López, M. Martin, and L. Darwich, "Microbiological diagnosis and antimicrobial sensitivity profiles in diseased free-living raptors," Avian Pathology, vol. 46, no. 4, pp. 442-450, 2017.

[25] A. I. Vela, E. Casas-Díaz, J. F. Fernández-Garayzábal et al., "Estimation of cultivable bacterial diversity in the cloacae and pharynx in Eurasian griffon vultures (Gyps fulvus)," Microbial Ecology, vol. 69, no. 3, pp. 597-607, 2015.

[26] C. Konicek, P. Vodrážka, P. Barták et al., "Detection of zoonotic pathogens in wild birds in the cross-border region Austria-Czech republic," Journal of Wildlife Diseases, vol. 52, no. 4, pp. 850-861, 2016. 
[27] J. Wang, Z. B. Ma, Z. L. Zeng, X. W. Yang, Y. Huang, and J. H. Liu, "The role of wildlife (wild birds) in the global transmission of antimicrobial resistance genes," Zoological Research, vol. 38, no. 4, pp. 55-80, 2017.

[28] P. Nordmann, G. Cuzon, and T. Naas, "The real threat of Klebsiella pneumoniae carbapenemase-producing bacteria," The Lancet Infectious Diseases, vol. 9, no. 4, pp. 228-236, 2009.

[29] I. Stolle, E. Prenger-Berninghoff, I. Stamm et al., "Emergence of OXA-48 carbapenemase-producing Escherichia coli and Klebsiella pneumoniae in dogs," Journal of Antimicrobial Chemotherapy, vol. 68, no. 12, pp. 2802-2808, 2013.

[30] M. E. Olson, H. Ceri, D. W. Morck, A. G. Buret, and R. R. Read, "Biofilm bacteria: formation and comparative susceptibility to antibiotics," Canadian journal of veterinary research, vol. 66, no. 2, pp. 86-92, 2002.

[31] N. Nandanwar, T. Janssen, M. Kühl, N. Ahmed, C. Ewers, and L. H. Wieler, "Extraintestinal pathogenic Escherichia coli (ExPEC) of human and avian origin belonging to sequence type complex 95 (STC95) portray indistinguishable virulence features," International Journal of Medical Microbiology, vol. 304, no. 7, pp. 835-842, 2014.

[32] L.-O. Chuah, A.-K. Shamila Syuhada, I. Mohamad Suhaimi, T. Farah Hanim, and G. Rusul, "Genetic relatedness, antimicrobial resistance and biofilm formation of salmonella isolated from naturally contaminated poultry and their processing environment in northern Malaysia," Food Research International, vol. 105, pp. 743-751, 2018.

[33] D. A. Rossi, R. T. Melo, E. P. Mendonça, and G. P. Monteiro, "Biofilms of salmonella and campylobacter in the poultry industry," in Poultry Science, M. Manafi, Ed., InTechOpen, pp. 93-113, London, UK, 2017.

[34] A. T. Lord, K. Mohandas, S. Somanath, and S. Ambu, "Multidrug resistant yeasts in synanthropic wild birds," Annals of Clinical Microbiology and Antimicrobials, vol. 9, no. 11, pp. 1-5, 2010.

[35] A. K. F. Costa, J. J. C. Sidrim, R. A. Cordeiro, R. S. N. Brilhante, A. J. Monteiro, and M. F. G. Rocha, "Urban pigeons (Columba livia) as a potential source of pathogenic yeasts: a focus on antifungal susceptibility of Cryptococcus strains in northeast Brazil," Mycopathologia, vol. 169, no. 3, pp. 207-213, 2010.

[36] C. Cafarchia, D. Romito, R. Iatta, A. Camarda, M. T. Montagna, and D. Otranto, "Role of birds of prey as carriers and spreaders of Cryptococcus neoformans and other zoonotic yeasts," Medical Mycology, vol. 44, no. 6, pp. 485492, 2006.

[37] M. Marinho, C. V. Táparo, B. G. D. Silva, L. N. Tencate, and S. H. V. Perri, "Microbiota fúngica de passeriformes de cativeiros da região noroeste do estado de São Paulo," Veterinária e Zootecnia, vol. 17, no. 2, pp. 288-292, 2010.

[38] J. H. Samour and J. L. Naldo, "Diagnosis and therapeutic management of candidiasis in falcons in Saudi Arabia," Journal of Avian Medicine and Surgery, vol. 16, no. 2, pp. 129-132, 2002.

[39] J. F. Mendes, A. P. N. Albano, M. A. A. Coimbra et al., "Fungi isolated from the excreta of wild birds in screening centers in Pelotas, RS, Brazil," Revista do Instituto de Medicina Tropical de São Paulo, vol. 56, no. 6, pp. 525-528, 2014.

[40] M. L. A. De Almeida, G. J. B. De Moura, D. S. Silva, and C. A. B. Santos, "Control and monitoring of the hunting fauna in the semi-arid region of Pernambuco: implications for conservation," International Journal of Development Research, vol. 8, no. 10, pp. 23728-23735, 2018.
[41] A. Garcês, I. Pires, F. Pacheco et al., "Natural and anthropogenic causes of mortality in wild birds in a wildlife rehabilitation centre in northern Portugal: a ten-year study," Bird Study, vol. 66, no. 4, pp. 484-493, 2019.

[42] L. T. R. Silva, J. S. A. Silva, D. C. V. Lima et al., "Anticorpos anti-Toxoplasma gondii em carcarás (Caracara plancus) procedentes da região aeroportuária do Recife, Pernambuco, Brasil," Arquivo Brasileiro de Medicina Veterinária e Zootecnia, vol. 70, no. 2, pp. 505-510, 2018.

[43] S. A. Suphoronski, T. D. F. Raso, N. C. Weinert, M. C. Seki, and A. D. O. T. Carrasco, "Occurrence of Salmonella sp. and Escherichia coli in free-living and captive wild birds from 2010-2013 in Guarapuava, Paraná, Brazil," African Journal Microbiology Research, vol. 9, pp. 1778-1782, 2015.

[44] J. Wu, Y. Huang, D. Rao, Y. Zhang, and K. Yang, "Evidence for environmental dissemination of antibiotic resistance mediated by wild birds," Frontiers in Microbiology, vol. 9, p. 745, 2018.

[45] B. Saud, G. Paudel, S. Khichaju et al., "Multidrug-resistant bacteria from raw meat of buffalo and chicken, Nepal," Veterinary Medicine International, vol. 2019, Article ID 7960268, 7 pages, 2019.

[46] A. A. Batalha De Jesus, A. A. R. Freitas, J. C. De Souza et al., "High-level multidrug-resistant Escherichia coli isolates from wild birds in a large urban environment," Microbial Drug Resistance, vol. 25, no. 2, pp. 167-172, 2019.

[47] D. P. Tubelis, "Aggregations of southern caracaras (Caracara plancus) in soybean plantations in central Cerrado, Brazil," Revista Brasileira de Ornitologia, vol. 27, no. 1, pp. 53-55, 2019.

[48] G. R. Quadra, P. S. A. Silva, J. R. Paranaíba et al., "Investigation of medicines consumption and disposal in Brazil: a study case in a developing country," Science of The Total Environment, vol. 671, pp. 505-509, 2019. 